\title{
LEAN IMPLEMENTATION STRATEGIES: HOW ARE THE TOYOTA WAY PRINCIPLES ADDRESSED?
}

\author{
R. Coetzee ${ }^{1 \#^{*}}$, K. van der Merwe ${ }^{2}$ \& L. van Dyk ${ }^{1}$
}

\section{ARTICLE INFO}

\section{Article details}

Presented at the $27^{\text {th }}$ annual conference of the Southern African Institute for Industrial Engineering (SAIIE), held from 27-29 October 2016 at Stonehenge in Africa, North West, South Africa

Available online 11 Nov 2016

Contact details

Corresponding author

Rojanette.Coetzee@nwu.ac.za

\section{Author affiliations}

1 Department of Industrial Engineering, North-west University, South Africa

2 Department of Industrial Engineering, Nelson Mandela Metropolitan University, South Africa

\# The author was enrolled for an PhD (Industrial) degree in the Department of Industrial Engineering, North-west University, South Africa

DOI

http://dx.doi.org/10.7166/27-3-1641

\section{ABSTRACT}

Lean manufacturing is widely considered to be a proven organisational improvement philosophy, yet the success rate of lean implementation in industry remains relatively low. Neglect of the human aspect of lean manufacturing is often cited as the leading reason for this, despite the emphasis so clearly placed upon this aspect by the creators of the lean philosophy. This article reviews the extent to which the human dimensions of the lean philosophy, as described in the Toyota Way management principles, have been incorporated in lean implementation strategies. It is found that few of the principles feature prominently in these strategies. Notably absent are those linked to the 'respect for people' pillar, which forms half of the Toyota Way's foundation. This conclusion indicates that the adoption of the lean philosophy runs contrary to the oft-repeated message from its creators that no tenet of the philosophy should be favoured at the expense of another. This may provide valuable insight into the reasons for the high implementation failure rate.

\section{OPSOMMING}

Alhoewel lenige (lean) vervaardiging algemeen aanvaar word as 'n erkende filosofie vir organisatoriese verbetering, bly die implementeringsukseskoers relatief laag. Dit word dikwels toegeskryf aan die verwaarlosing van die menslike aspek, ten spyte van die klem wat die stigters van die lenige filosofie op hierdie aspek plaas. Hierdie artikel beskou die mate waartoe hierdie menslike aspekte van lenig, soos beskryf in die 'Toyota Way' bestuursbeginsels, vervat is in lenige implementering-strategieë. Daar is gevind dat baie min van die beginsels prominent in die strategieë verskyn. Dit is veral opvallend dat die beginsels wat verband hou met die 'respek vir mense' pilaar, afwesig is alhoewel hierdie pilaar die helfte van die 'Toyota Way' fondasie uitmaak. Die gevolgtrekking word gemaak dat lenige implementeringstrategieë in kontras is met die dikwels herhaalde boodskap van die stigters van die lenige filosofie, dat geen beginsels ten koste van ander uitgesonder mag word nie. Dit mag ook waardevolle insig gee tot die rede vir onsuksesvolle lenige implementering.

\section{INTRODUCTION}

Improving operational performance is a key prerequisite for sustaining and growing an organisation. Lean manufacturing is widely considered to be a philosophy that brings about such continuous improvement. However, the success rate for lean implementation remains relatively low [1, 2]. Why is this? Prominent among the reasons cited is the intense focus on lean tools and techniques at the expense of the human side of lean management [3-6]. Employees often do not feel valued, even though they are the ones who are in the best position to offer suggestions for improving the efficiency of the work that they do [7]. A lack of training and resistance to change from both 
employees and managers contribute to the problem [8]. Bateman and Rich [9] concluded that a general lack of resources, the need for change, and employee turnover inhibit improvements in manufacturing processes. In order to increase the success of the lean transformations, it is important for employees to develop higher commitment levels, experience stronger beliefs, be exposed to greater communication, and cultivate better work methods [10]. People-related issues need to be addressed, since in most cases they are the critical success factors for projects [11].

Taiichi Ohno [12], the originator of the Toyota Production System (TPS), realised the importance of including people in achieving continuous improvement when he created "the second, and equally important pillar, namely respect for people" in his book, Toyota Production System: Beyond LargeScale Production. Similarly, Fujio Cho, Toyota's former chairman, emphasised the focus on people in the following famous statement: "First we build people, then we build cars" [13].

The involvement of employees in the continuous improvement process influences successful lean transformation. If employees adopt the change but are not committed to making change happen, the transformation can fail. It can thus be said that the success of a lean transformation lies substantially in the hands of the employees who are responsible for implementing the change. Stewart [14] agrees:

"In traditional organisations, it makes no difference what direction management want the company to take if the employees are not able to discern the fundamental purpose of what the company is trying to do. The greatest ideas for implementing any change in a work environment will fall flat unless the employees buy into it."

In the recent history of manufacturing, there have been various lean implementation strategies, such as the kaizen ${ }^{1}$ workshops, the enterprise-level transition to lean (TTL) roadmap, and the production operations-level TTL roadmap. Despite these strategies, the lean implementation success rate remains relatively low. Liker and Franz [1] claimed that they had not seen any successful continuous improvement outside of Japan, after they had visited hundreds of companies in a 10year period.

The hypothesis advanced in this article, therefore, is that a lack of people principles in these strategies is a fundamental reason for failures in lean implementation.

\section{PURPOSE AND METHODOLOGY}

It seems that Taiichi Ohno's 'respect of people' pillar is given less attention than it should receive $[11,15]$. The purpose of the study reported in this article is to determine the extent to which the Toyota Way management principles have been incorporated in lean implementation strategies.

This objective is accomplished by first noting the differences between the concepts of continuous improvement, lean manufacturing, the TPS, and the Toyota Way, in Section 3. A summary of the 14 Toyota Way management principles then follows in Section 4. Five lean implementation strategies are reviewed and summarised in Section 5 according to themes that are evident in most of them. These strategies are then analysed in terms of the Toyota Way management principles, in Section 6.

\section{DEFINING CONTINUOUS IMPROVEMENT, KAIZEN, LEAN MANUFACTURING, TPS, AND THE TOYOTA WAY}

The terms 'continuous improvement' $(\mathrm{Cl})$, 'lean manufacturing', 'TPS', and 'the Toyota Way' are often used interchangeably without a full appreciation of the fundamental differences between them. Stewart [14] and Liker [13] warn that this misconception could have a negative effect on an organisation. Many companies implement management tools such as kanban ${ }^{2}$ and poka-yoka ${ }^{3}$ and realise substantial benefits in a short time, but unless they make an effort also to understand the broader system, they will never reach the true potential that they offer. This practice of selecting

Japanese term meaning continuous improvement.

Japanese term meaning 'signal', used for just-in-time production scheduling.

Japanese term meaning 'inadvertent error prevention'. 
specific elements of the lean philosophy to implement is not necessarily bad, but it limits the results and ultimately leads to frustration $[13,14]$.

$\mathrm{Cl}$ is a philosophy that Deming [16] described as "improvement initiatives that increase success and reduce failures". Another definition of $\mathrm{Cl}$ is "a company-wide process of focused and continuous incremental innovation" [17]. Examples of such Cl initiatives or methodologies are the Theory of Constraints (TOC), Six Sigma, Total Quality Management (TQM), Balanced Scorecard, and lean manufacturing $[16,18]$.

One of the principles within lean manufacturing is kaizen. The term, which literally means change (kai) for the better (zen), has been around for so long that most non-Japanese books no longer even italicise it as a foreign word [1]. The problem with it being around for so long is that the misconception has developed over time that kaizen and $\mathrm{Cl}$ are synonyms and can be used interchangeably. This, however, is not the case - kaizen is only the $\mathrm{Cl}$ aspect within lean manufacturing [16].

To summarise, lean manufacturing is seen as one of many $\mathrm{Cl}$ strategies, and kaizen is a fundamental part of lean manufacturing; but these concepts are not synonymous (Figure 1).

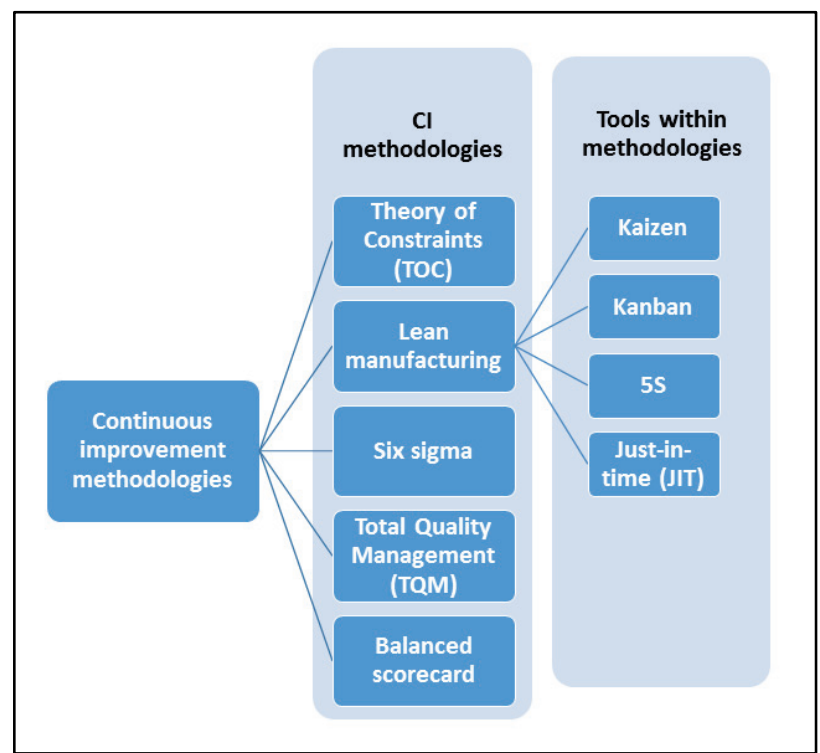

Figure 1: Schematic illustration of the differences between $\mathrm{Cl}$, lean manufacturing, and kaizen

The lean movement was launched when Womack and associates released the ground-breaking book, The Machine that Changed the World [19], in 1990. It was in this work that they labelled the new Toyota paradigm of manufacturing by doing more with less as "lean production" [1]. It is noteworthy that the term 'lean' was never used historically within Toyota [19, 20].

Stewart [14] explains the meaning of lean manufacturing and TPS as follows:

"The difference between lean manufacturing and TPS is that in lean manufacturing the focus is on the tools, and with TPS the focus is on the system. There are many tools (just-in-time, cells, 5S, kanban, etc.) that can be utilised to implement the TPS, but not all are mandatory."

Unlike lean manufacturing, TPS should never be seen as a toolkit; it is a sophisticated production system in which all of the parts contribute to a whole. At its root, TPS focuses on supporting and encouraging people to continually improve the process that they are working on [13,14]. Therefore, people are the centre of the TPS house (Figure 2a). 


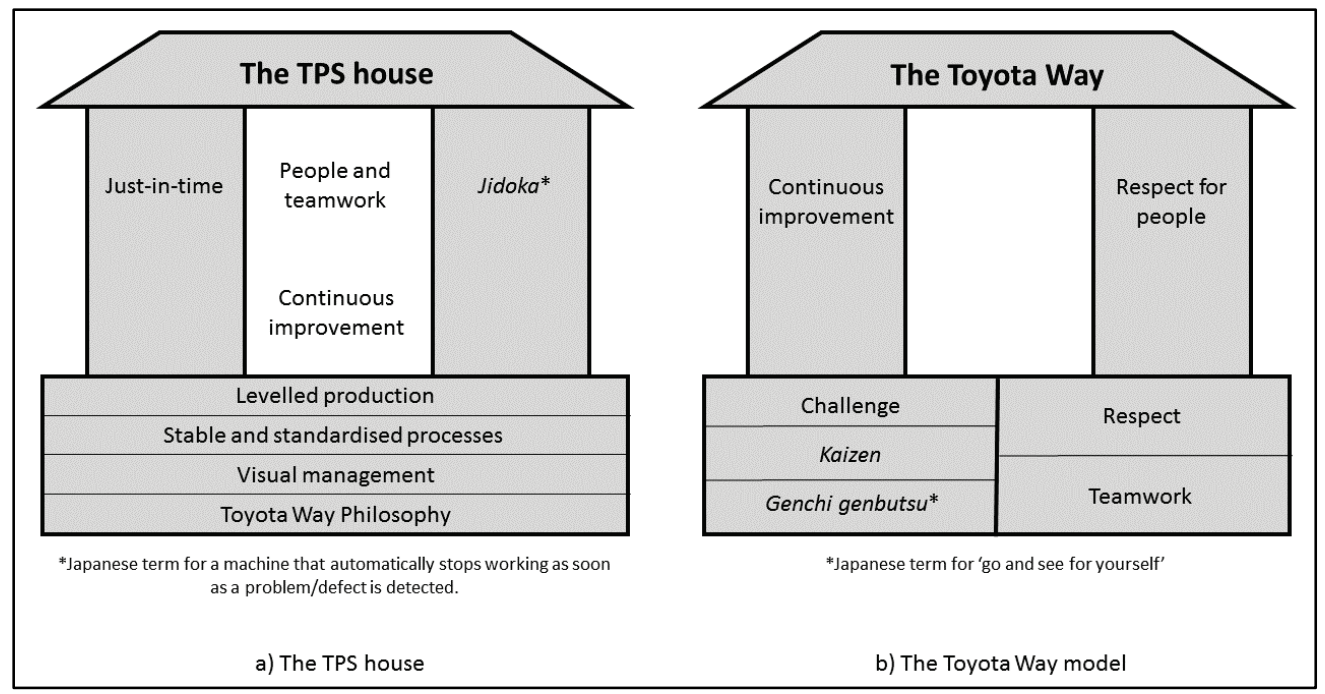

Figure 2: Illustrating the difference between the TPS house (adapted from [13]) and the Toyota Way 2001 model (adapted from [20]) in terms of their foundations and pillars

The Toyota Way is not explained as a system, process, or programme. Instead, it is a mindset that explains how thoughts and actions guide people to interact with each other on a daily basis. The Toyota Way can also be seen as an organisational culture. Fujio Cho, Toyota's former president, originally published the Toyota Way model in 2001 when he realised that there was too much inconsistency among Toyota managers in their understanding of what made the company tick. According to Cho, the Toyota Way model is a basis for daily management that is centred on two principles: Respect for people, and Continuous improvement (Kaizen) [14, 21]. These two pillars summarise the model and indicate that Cho wanted to emphasise the important part that people play in the change process.

In 2004, Jeffrey Liker wrote The Toyota Way - 14 Management principles [13], after spending 20 years working in Toyota factories in Japan and the United States. The Toyota Way reveals the 14 foundational management principles behind the giant automaker's world-famous production system. Liker [13] divided these principles into the 4P model, which consists of the following four categories: philosophy, process, people and partners, and problem-solving.

Figure 2 illustrates simplified versions of the TPS house and the Toyota Way model. The only aspects of the principles illustrated are the pillars and the foundations. It can be seen that the Toyota Way model incorporates the TPS house and is quite different in emphasis. In the latter, the core pillars are just-in-time and jidoka $a^{4}$ (intelligent autonomation ${ }^{5}$ ), which are both technical concepts. In contrast, the pillars of the Toyota Way model focus on people: $\mathrm{Cl}$ and respect for each other [20].

\section{REVIEW: THE TOYOTA WAY}

As previously stated, the Toyota Way model is centred on two principles: 'Continuous improvement' and 'Respect for people', which are built on three and two foundational blocks respectively, as shown in Figure $2 \mathrm{~b}$.

$\mathrm{Cl}$ is built on [20]:

- Challenge: Form a long-term vision, meeting challenges with courage and creativity to realise dreams.

- $\quad$ Kaizen: Improve business operations continuously, always striving for innovation and evolution.

\footnotetext{
4 Japanese term for a machine that stops working as soon as a problem/defect is detected.

5 It may be described as 'intelligent automation' or 'automation with a human touch'.
} 
- Genchi genbutsu ${ }^{6}$ : believing in going to the source to find the facts and to make correct decisions, building consensus, and achieving goals at the best speed.

Respect for people is built on [20]:

- $\quad$ Respect: Respect each other, make every effort to understand each other, take responsibility, and build mutual trust.

- Team work: Stimulate personal and professional growth, share the opportunities of development, and maximise individual and team performance.

\subsection{The 14 Toyota Way management principles}

In order to illustrate the 14 Toyota Way management principles [13] in terms of the two pillars that were created by Fujio Cho (quoted by Stewart [14]), the principles have been categorised in terms of the two pillars in Figure 3.

\begin{tabular}{|c|c|c|c|}
\hline \multirow{14}{*}{ 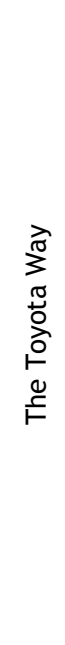 } & \multirow{9}{*}{ 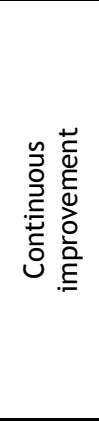 } & Challenge & 1. Long-term philosophy \\
\hline & & \multirow{8}{*}{ Kaizen } & 2. Create flow \\
\hline & & & 3. Use a pull system \\
\hline & & & 4. Level out the workload \\
\hline & & & 5. Stop and fix the problem \\
\hline & & & 6. Standardise tasks \\
\hline & & & 7. Use visual control \\
\hline & & & 8. Use reliable, tested technology \\
\hline & & & 14. Continual organisational learning through kaizen \\
\hline & \multirow{5}{*}{ 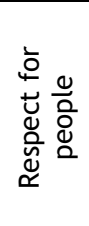 } & \multirow{2}{*}{$\begin{array}{l}\text { Genchi } \\
\text { genbutsu }\end{array}$} & 12. Go and see for yourself to understand the situation \\
\hline & & & 13. Make decisions slowly by consensus \\
\hline & & \multirow{2}{*}{ Respect } & 9. Grow leaders who live the philosophy \\
\hline & & & 11. Respect, challenge, and help your suppliers \\
\hline & & Teamwork & 10. Respect, develop, and challenge your people and teams \\
\hline
\end{tabular}

Figure 3: Summary of the Toyota Way, including the 14 management principles

While the Toyota Way is summarised by these two pillars, the next section addresses the relationship between the two pillars.

\subsection{The relationship between 'Continuous improvement' and 'Respect for people'}

According to Convis ${ }^{7}$, and as quoted by Liker [13], there is something more important than the actual improvements that individuals contribute:

"The true value of continuous improvement is in creating an atmosphere of continuous learning and an environment that not only accepts, but actually embraces change. Such an environment can only be created where there is respect for people - hence the second pillar of the Toyota Way."

The questions that arise are: Exactly what does respect for people entail? and How does it relate to $\mathrm{Cl}$ ? According to Womack [22], most managers are under the impression that if employees are treated fairly, given clear goals, trusted to achieve them in the best way, and held to account for results, they receive respect. But this is not the case. It is through the problem-solving process that true respect is shown $[22,23]$. Ignoring the priceless inputs that workers can give is seen as disrespectful $[14,24]$. It is only by implementing the problem-solving process effectively that there will be $\mathrm{Cl}$ in an organisation.

However, if there is no policy to capture employees' ideas that will move the company forward, motivating the workforce becomes nearly impossible, since motivation comes from the top and

\footnotetext{
Japanese term for 'go and see for yourself' truly to understand the situation.

7 Managing Officer of Toyota and President of Toyota Motor Manufacturing, Kentucky.
} 
generally does not trickle down to the workers on the shop floor. A CEO's speech can get the front offices really fired up and energised, only to be lost on the people who actually perform the work [14].

Womack [22] explains how the problem-solving process should be followed in order to show mutual respect between managers and workers:

- Manager(s) will ask the employee(s) what the problem is that they are experiencing. A dialogue will follow to determine the true problem (not just the surface problem).

- $\quad$ The possible root cause will be discussed after the worker has gathered sufficient evidence by means of the genchi genbutsu principle.

- The employee is given the opportunity to make suggestions about solving the problem and to explain the reason for the chosen solution.

- Employees are also required to make suggestions about the best indicators of when the problem is solved.

- $\quad$ Finally, after agreement is reached on the most appropriate measure of success, the employees set out to implement the solution.

By following this process, respect is shown to the employee. The manager admits that he/she cannot solve the problem alone, since he/she is not close enough to the problem to know all the facts. Moreover, the manager is showing true respect for the employees' knowledge and their dedication to finding the best answer. On the other hand, the employees cannot solve the problem alone, since they are too close to the problem to see its context, and they might not ask tough questions about their own work.

"Only by showing mutual respect - each for the others and for each other's role - is it possible to solve problems, make work more satisfying and take organizational performance to an even higher level." [22]

The $\mathrm{Cl} /$ Respect-for-people relationship has been explained, and the importance of including people in the problem-solving process has been emphasised. The question remains as to whether "respect for people" has been incorporated in the lean manufacturing continuous improvement strategies.

\section{REVIEW: LEAN IMPLEMENTATION STRATEGIES}

Table 1 is used to introduce different lean implementation strategies (columns) and map them against different themes (rows). The lean implementation strategies that are described are the following:

1. Tips for a lean transition [13].

2. Prerequisites for a lean transition [4].

3. Transition to Lean (TTL) roadmap: Production operations level [25].

4. Transition to Lean (TTL) roadmap: Enterprise level [26].

5. Kaizen workshops [27].

The themes according to which the implementation strategies are mapped are the following:

1. Creating a vision.

2. Preparation.

3. Value-stream mapping.

4. Employee empowerment.

5. Implementation planning.

6. Implementation.

7. $\mathrm{Cl}$.

In Table 1, the original sequence of the implementation strategies may have been changed for grouping purposes, but the number in front of each step of each strategy (columns) reflects the original order. Strategies 1, 2, and 5 are designed as simple steps, and are simply listed in Table 1. On the other hand, the TTL roadmaps contain more information and therefore, in addition to Table 1 , are elaborated on in Sections 5.1 and 5.2. 
Table 1: Lean implementation strategies

\begin{tabular}{|c|c|c|c|c|c|}
\hline & Tips for a lean transition [13] & $\begin{array}{l}\text { Prerequisites for a lean } \\
\text { transition [4] }\end{array}$ & TTL - Production operation level [25] & TTL - Enterprise level [26] & Kaizen workshop [27] \\
\hline 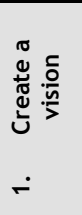 & & $\begin{array}{l}\text { - The enterprise should } \\
\text { have a vision } \\
\text { - Create a sense of urgency } \\
\text { - The need to produce } \\
\text { short-term results must } \\
\text { be created }\end{array}$ & $\begin{array}{l}\text { Phase 0: Adoption of the lean paradigm } \\
\text { - Build vision } \\
\text { - Establish need } \\
\text { - Foster lean learning } \\
\text { - Make the commitment } \\
\text { - Obtain senior management buy-in }\end{array}$ & $\begin{array}{l}\text { 1. Adopt a lean paradigm } \\
\text { - Build vision } \\
\text { - Convey urgency } \\
\text { - Foster lean learning } \\
\text { - } \text { Make the commitment } \\
\text { Obtain senior management } \\
\text { buy-in }\end{array}$ & \\
\hline 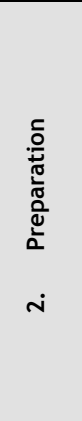 & $\begin{array}{l}\text { - Use Kaizen workshops to } \\
\text { teach and make rapid } \\
\text { changes. } \\
\text { - Be opportunistic in } \\
\text { identifying opportunities } \\
\text { - Make the change mandatory }\end{array}$ & $\begin{array}{l}\text { Agree on the duration of } \\
\text { the project prior to its } \\
\text { commencement } \\
\text { - Fear and anxiety should } \\
\text { be removed }\end{array}$ & $\begin{array}{l}\text { Phase 1: Prepare implementation } \\
\text { - Integrate with the enterprise level } \\
\text { - Develop an implementation strategy } \\
\text { - Develop a plan to address workforce } \\
\text { - changes } \\
\text { - Eddress site-specific cultural issues } \\
\text { Establish target objectives (metrics) }\end{array}$ & & $\begin{array}{l}\text { 1. Prepare for the workshop } \\
\text { - } \text { Define the scope of the problem } \\
\text { - } \text { Decide on a team } \\
\text { sollect data on the current } \\
\text { situation } \\
\text { - Decide what lean tools to use } \\
\text { evenistical arrangements for the } \\
\text { 2. Day } 1 \\
\text { - Overview of lean manufacturing } \\
\text { - Teach special tools needed for } \\
\text { the workshop } \\
\text { - Collect data on the current } \\
\text { process }\end{array}$ \\
\hline 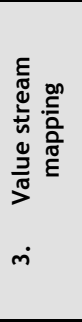 & $\begin{array}{l}\text { Realign metrics with a } \\
\text { value-stream perspective }\end{array}$ & & \begin{tabular}{|l} 
Phase 2: Define value \\
- Select initial implementation scope \\
- $\quad$ Define the customer \\
Pefine the value \\
Phase 3: Identify the flow of value \\
- Record the current-state value stream \\
- Chart the product \& information flow \\
- Chart operator movement \\
- Cort tool movement \\
Collect baseline data
\end{tabular} & $\begin{array}{l}\text { 2. Focus on the value stream } \\
\text { - } \frac{\text { Map the value stream }}{\text { Internalise the vision }} \\
\text { - Set goals \& metrics } \\
\text { Identify \& involve key } \\
\text { stakeholders }\end{array}$ & $\begin{array}{l}\text { 3. Day } 2 \\
\text { - Complete the current state } \\
\text { analysis } \\
\text { - Collect data } \\
\text { - Draw a process flow map } \\
\text { - Draw a walk pattern on layout } \\
\text { o } \quad \text { Develop standardised work } \\
\\
\text { combination tables } \\
\text { Develop ideas for the } \\
\text { improved state } \\
\text { Draft the future state }\end{array}$ \\
\hline
\end{tabular}




\begin{tabular}{|c|c|c|c|c|c|}
\hline & Tips for a lean transition [13] & $\begin{array}{l}\text { Prerequisites for a lean } \\
\text { transition }[4]\end{array}$ & TTL - Production operation level [25] & TTL - Enterprise level [26] & Kaizen workshop [27] \\
\hline 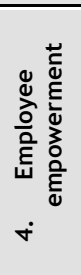 & $\begin{array}{l}\text { - Use experts for teaching } \\
\text { - Hire or develop lean } \\
\text { leaders and develop a } \\
\text { succession system } \\
\text { - Learn by doing first and } \\
\text { training second }\end{array}$ & $\begin{array}{l}\text { - Empower employees to } \\
\text { create the change } \\
\text { - Make use of a sensei } i^{8} \\
\text { throughout the } \\
\text { transformation } \\
\text { - Assemble a strong enough } \\
\text { team } \\
\text { - Ensure employee } \\
\text { engagement }\end{array}$ & $\begin{array}{l}\text { Phase } 19: \text { Prepare implementation } \\
\text { - Train key people } \\
\text { - Establish an operations lean } \\
\text { implementation team(s) }\end{array}$ & $\begin{array}{l}\text { 3. Develop lean structures \& } \\
\text { behaviour } \\
\text { - Organise for lean } \\
\text { implementation } \\
\text { - Identify \& empower change } \\
\text { agents } \\
\text { - Align incentives } \\
\text { - Adapt structure \& systems }\end{array}$ & \\
\hline 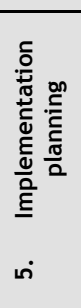 & & & 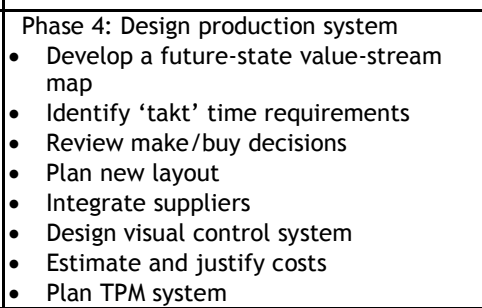 & $\begin{array}{l}\text { 4. Create \& refine } \\
\text { transformation plan } \\
\text { - Identify \& prioritise activities } \\
\text { - Commit resources } \\
\text { - Provide education \& training }\end{array}$ & \\
\hline 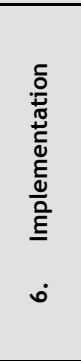 & $\begin{array}{l}\text { Start with action in the } \\
\text { technical system; follow } \\
\text { quickly with culture change }\end{array}$ & & $\begin{array}{l}\text { Phase 5: Implement flow } \\
\text { - Standardise operations } \\
\text { - Mistake-proof processes } \\
\text { - Achieve process control } \\
\text { - Implement total productive } \\
\text { - maintenance } \\
\text { - Implement self-inspection } \\
\text { - Eliminate/reduce waste } \\
\text { - } \text { Ress-train workforce } \\
\text { - Implement-up times } \\
\text { - Implement visual controls }\end{array}$ & $\begin{array}{l}\text { 5. Implement lean initiatives } \\
\text { - Develop detailed plans } \\
\text { - Implement lean activities }\end{array}$ & $\begin{array}{l}\text { 4. Day } 3 \\
\text { - Implementation (pilot of full) }\end{array}$ \\
\hline
\end{tabular}

8 Japanese term for 'teacher'

9 Phase 1 partially repeated to align training people point with other employee-related steps 


\begin{tabular}{|c|c|c|c|c|c|}
\hline & Tips for a lean transition [13] & $\begin{array}{l}\text { Prerequisites for a lean } \\
\text { transition [4] }\end{array}$ & TTL - Production operation level [25] & TTL - Enterprise level [26] & Kaizen workshop [27] \\
\hline 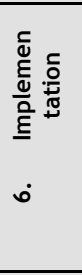 & $\begin{array}{l}\text { 7. Start with action in the } \\
\text { technical system; follow } \\
\text { quickly with culture } \\
\text { change (continued) }\end{array}$ & & $\begin{array}{l}\text { Phase 6: Implement pull system } \\
\text { - Select an appropriate production } \\
\text { system control mechanism } \\
\text { - Strive for single item flow } \\
\text { - Level \& balance production flow } \\
\text { - Link with suppliers } \\
\text { - } \text { Draw down inventories } \\
\text { - Reassign people } \\
\text { Re-deploy/dispose assets }\end{array}$ & & \\
\hline 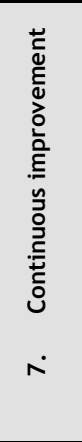 & $\begin{array}{l}\text { A crisis may prompt a lean } \\
\text { movement, but may not be } \\
\text { necessary to turn a } \\
\text { company around } \\
\text { Build on your company's } \\
\text { roots to develop your own } \\
\text { way }\end{array}$ & & $\begin{array}{l}\text { Phase 7: Strive for perfection } \\
\text { - } \text { Team development } \\
\text { - Optimise quality } \\
\text { - Institutionalise } 55^{10} \\
\text { - Institute kaizen events } \\
\text { - Remove system barriers } \\
\text { - Evand TPM } \\
\text { - Evaluate against target metrics } \\
\text { matrices }\end{array}$ & $\begin{array}{l}\text { 6. Focus on } \mathrm{Cl} \\
\text { - } \\
\text { - Nonitor lean progress } \\
\text { - Refure the process } \\
\text { - } \text { Capture \& adan } \\
\text { knowledge }\end{array}$ & $\begin{array}{l}\text { 5. Day } 4 \\
\text { - } \text { Evaluate the process (Check) } \\
\text { - Improve (Act) } \\
\text { - Continue PDCA cycle until a good } \\
\text { approach is available } \\
\text { 6. Day } 5 \\
\text { - Develop a presentation for } \\
\text { management } \\
\text { - Present to management } \\
\text { 7. Follow-up after workshop } \\
\text { - Prepare action plan during } \\
\text { workshop for items that could not } \\
\text { be completed during the } \\
\text { workshop. } \\
\text { - Follow up on these items }\end{array}$ \\
\hline
\end{tabular}

$105 \mathrm{~S}$ is the name of a workplace organisation method that uses five Japanese words: seiri (sort), seiton (set), seiso (shine), seiketsu (standardise), and shitsuke (sustain). 


\subsection{TTL roadmap: Production operation level}

The production operations TTL roadmap can be used by organisations with existing operations to implement the lean manufacturing philosophy and lean best practices. The model is divided into eight phases: these indicate points that interface with other systems that are internal and external to the business enterprise. The implementation is systematic, with milestones in a specific order of precedence [25]. Table 1 gives details of the implementation phases.

\subsection{TTL roadmap: Enterprise level}

The enterprise TTL roadmap was developed to assist organisations in their efforts to transform into lean enterprises. The framework portrays the overall 'flow' of action steps necessary to initiate, sustain, and continuously refine a company based upon lean principles and practices. The roadmap was developed from an enterprise perspective, with particular attention paid to strategic issues, internal and external relations with all key stakeholders, and structural issues that must be addressed during a significant change initiative [26].

The roadmap consists of three interdependent 'cycles' [26]. Figure 4 and column 4 of Table 1 illustrate the detailed steps of the TTL roadmap:

1. Entry/re-entry cycle: The environment and conditions necessary for a successful transformation are created, including preparing for the launch into detailed planning and implementation:

- Adopt a lean paradigm.

2. Long-term cycle: Detailed implementation is planned, executed, and monitored. It includes ongoing monitoring and corrective actions:

- Focus on the value stream.

- Develop lean structures and behaviour.

3. Short-term cycle: This cycle is re-entered periodically to capitalise on lessons learned during implementation, and to accommodate changes occurring in the dynamic external environment:

- Create and refine the transformation plan.

- Implement lean initiatives.

- Focus on $\mathrm{Cl}$.

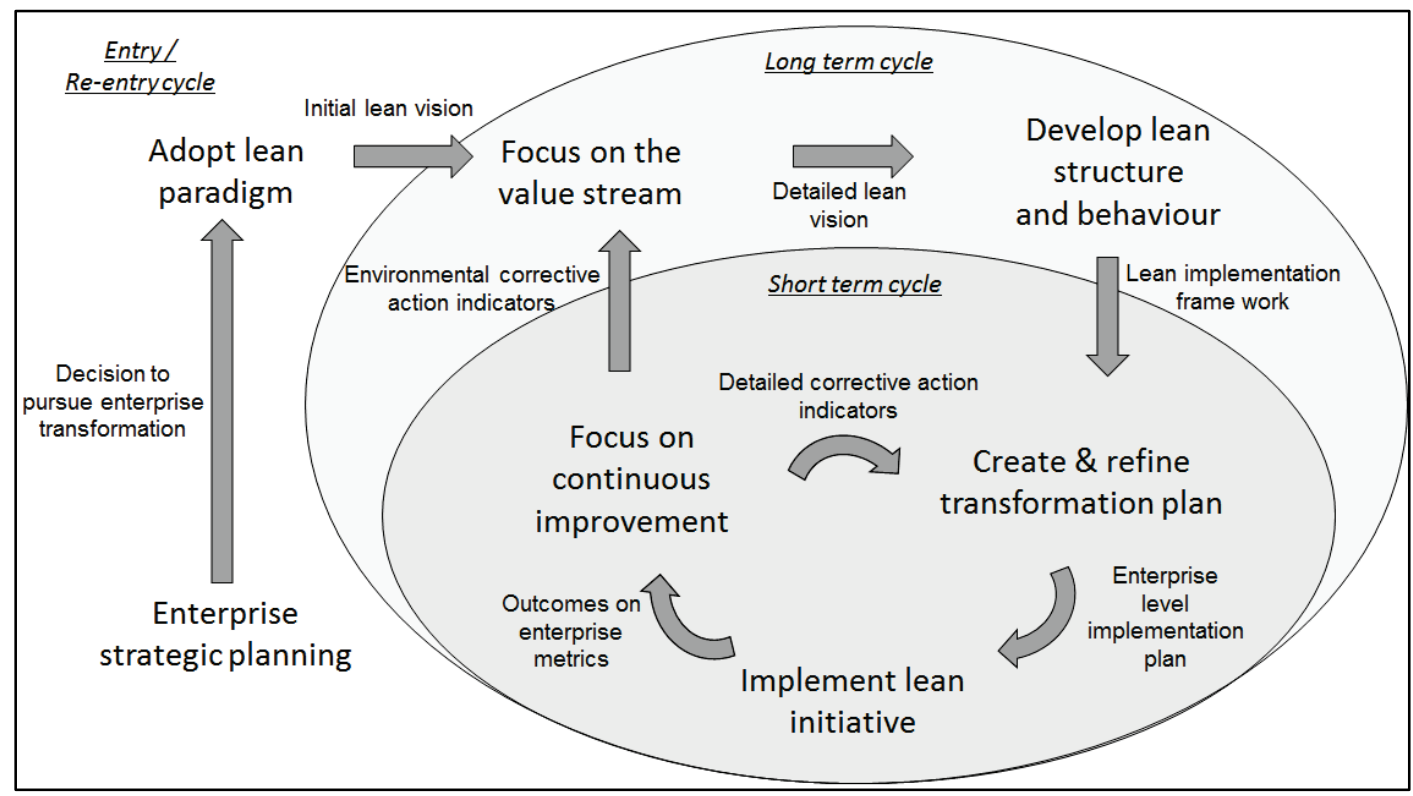

Figure 4: Enterprise level transition to lean roadmap, indicating the three interdependent cycles of implementation (adapted from [26]) 
Table 2 summarises how the 14 Toyota Way management principles (discussed in Section 4.1) have been incorporated into the lean implementation strategies (discussed in Section 5). The rows represent the 14 Toyota Way management principles, and each column represents one of the lean implementation strategies. Assuming an absolute value of 'yes' or 'no', each dot indicates that the particular Toyota Way principle has been incorporated into the specific lean implementation strategy. The columns on the right indicate how many of the implementation strategies incorporated a particular Toyota Way principle.

Table 2: Toyota Way principles incorporated into lean implementation strategies

\begin{tabular}{|c|c|c|c|c|c|c|c|}
\hline \multicolumn{2}{|c|}{ Toyota Way Principles } & Tips & Prereq. & Prod. TTL & Enterp. TTL & Kaizen workshop & Total \\
\hline$\frac{5}{\alpha}$ & 1 & & • & • & • & & 3 \\
\hline \multirow{7}{*}{ 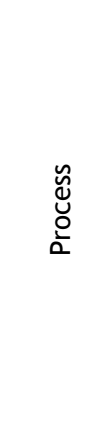 } & 2 & $\bullet$ & & • & • & • & 4 \\
\hline & 3 & & & • & & & 1 \\
\hline & 4 & & & & & & 0 \\
\hline & 5 & & & & & & 0 \\
\hline & 6 & & & • & & & 1 \\
\hline & 7 & & & • & & & 1 \\
\hline & 8 & & & & & & 0 \\
\hline \multirow{3}{*}{ 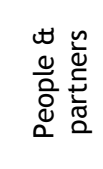 } & 9 & • & • & & & & 2 \\
\hline & 10 & $\bullet$ & • & • & • & & 4 \\
\hline & 11 & & & & & & 0 \\
\hline \multirow{3}{*}{ 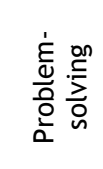 } & 12 & & & & & & 0 \\
\hline & 13 & & & & & & 0 \\
\hline & 14 & & & • & • & $\bullet$ & 3 \\
\hline
\end{tabular}

\subsection{Philosophy}

Three of the five implementation strategies discuss the need for vision. In terms of implementation, a vision could be seen as a philosophy.

\subsection{Process}

Within the process group of principles, the focus is mainly on flow (Principle 2), pull (Principle 3), and value-stream mapping. Standardised tasks (Principle 6) and visual management (Principle 7) are mentioned only in the production operations TTL roadmap.

These are all positive contributions to the general implementation success, but there is great room for improvement in this layer of the 4P model of the Toyota Way. None of the strategies mentions levelling out the workload (Principle 4) or steps in creating a culture that will stop and fix problems (Principle 5). There is also no indication of how technology will be evaluated for implementation (Principle 8).

Liker [13] is of the opinion that most companies focus on the 'process' layer of the 4P model when attempting a lean transformation. However, our study does not indicate this. Considering the large number of principles that are included in this layer of the 4P model, the percentage implementation might not be an accurate indication of the industry. What Liker [13] might have implied is that, of all the principles that a specific company adopts, most of their time and effort goes into the technical 'process' layer of the 4P model. 


\subsection{People and partners}

According to Table 2, four of the five strategies mention developing people or teams (Principle 10), but only two discuss developing leaders (Principle 9). This might be a contributing factor to the failures in lean implementation.

Bessant [17] concurs that the literature dealing with lean production systems (LPS) and CI does not cover behavioural aspects of the change process. One such example relates to deficiencies in the LPS implementation roadmaps that closely correlate results with the exposure to lean techniques, neglecting elements such as the development of behaviour. The literature sometimes assumes a binary division between having a TPS or not, rather than viewing it as an emerging behavioural pattern to be developed in alignment with a management philosophy [28, 29].

\subsection{Problem-solving}

Lean implementation strategies focus the least on principles in the problem-solving layer. This is a point of concern, since the reason for implementing lean principles is for $\mathrm{Cl}$, which cannot be achieved without solving problems.

Some focus is given to becoming a learning organisation by means of $\mathrm{Cl}$ (Principle 14), but no attention is given to the 'go and see' principle (Principle 12) or the 'make decisions slowly by consensus' principle (Principle 13). Principle 12 is important in order to understand the organisation's problems that need to be solved or improved. Furthermore, Principles 12 and 13 are important ways of including people in the problem-identification and -solving process.

\section{DISCUSSION}

This article has elaborated on the content of the Toyota Way, and revealed the important link between the 'continuous improvement' pillar and the 'respect for people' pillar, emphasising the importance of including people in the $\mathrm{Cl}$ problem-solving process. Different lean implementation strategies have been analysed, and they have revealed how few of the Toyota Way management principles have been included. This might provide insight into the failures in lean implementation.

The main point of concern demonstrated by this article is the $\mathrm{Cl} /$ Respect-for-people relationship, which is not included in any of the lean implementation strategies. This might be the fundamental reason why the lean implementation success rate is so low, since the importance of including people in the problem-solving process has been emphasised throughout this article.

This crucial finding on lean implementation failures confirms and elaborates on what is written in the literature: "By concentrating on the tangible outcomes, organisations lose sight of the intangible aspects of change and culture, and in particular that companies are formed out of people" [4]. Furthermore, attempting to adopt any $\mathrm{Cl}$ initiative without incorporating aspects that prove that there is respect for the people who have to undergo the change, will simply not deliver the required results [23]. This article has demonstrated that this is indeed the case with prevailing lean implementation strategies.

Production management consists of both technological and human elements. The Toyota system is a monument in the history of production management because it requires an entirely new way of analysing both of these elements simultaneously under one scheme [30]. Unfortunately, it seems that "the second, and equally important pillar" [12], 'respect for people', has largely been forgotten. The research conducted in this study and reported in this article can assist organisations to be more aware of the human element in order to make it a prominent feature in lean implementation strategies.

\section{FURTHER RESEARCH}

There remains a need for further research into including the Toyota Way management principles more prominently in lean implementation strategies, with an emphasis on the suggested problemsolving process, in order to increase the success rate of lean implementations. These improved implementation strategies can then be developed into effective and strategic lean implementation plans. 
Further evidence is also required from industry to determine whether people are included in the $\mathrm{Cl}$ problem-solving process. This article has stated that the main point of concern is the $\mathrm{Cl} /$ Respectfor-people relationship, which is not included in any of the lean implementation strategies. It is suggested that this might be a fundamental reason why the lean implementation success rate is so low. Evidence from industry is required to prove this hypothesis.

\section{REFERENCES}

[1] Liker, J. and Franz, J. 2011. The Toyota Way to continuous improvement. McGraw Hill.

[2] Bhasin, S. 2012. Prominent obstacles to lean. International Journal of Productivity and Performance Management, 61(4), pp. 403-425.

[3] Nordin, N., Deros, B.M. and Wahab, D.A. 2011. Lean manufacturing implementation in Malaysian automotive industry: An exploratory study. Operations and Supply Chain Management, 4(1), pp. 21-30.

[4] Bhasin, S. 2012. An appropriate change strategy for lean success. Management Decision, 50(3), pp. 439458.

[5] Miller, M., Brom, M. and Houge, J. Building a lean enterprise culture. Presented at Institute of Industrial Engineers Lean Management Solutions Conference, St. Louis, September, 2001

[6] Pakdil. F. and Leonard, K.M. 2014. Criteria for a lean organisation: Development of a lean assessment tool. International Journal of Production Research, 52(15), pp. 4587-4607.

[7] Sim, K.L. and Rogers, J.W. 2008. Implementing lean production systems: Barriers to change. Management Research News, 32(1), pp. 37-49.

[8] Shang, G. and Pheng, L.S. 2014. Barriers to lean implementation in the construction industry in China. Journal of Technology Management in China, 9(2), pp. 155-173.

[9] Rich, N. and Bateman, N. 2003. Companies' perceptions of inhibitors and enablers for process improvement activities. International Journal of Operations \& Production Management, 23(2), pp. 185199.

[10] Losonci, D., Demeter, K. and Jenei, I. 2011. Factors influencing employee perceptions in lean transformations. International Journal of Production Economics, 131(1), pp. 30-43.

[11] Gao, S. and Low, S.P. 2015. Toyota way style human resource management in large Chinese construction firms: A qualitative study. International Journal of Construction Management, 15(1), pp. 17-32.

[12] Ohno, T. 1988. Toyota production system: Beyond large-scale production. Oregon: Productivity Press.

[13] Liker, J.K. 2004. The Toyota way - 14 management principles. McGraw-Hill.

[14] Stewart, J. 2012. The Toyata Kaizen continuum: A practical guide to implementing lean. CRC Press.

[15] Nordin, N., Derios, B.M., Wahab, D.A. and Rahman, M.N.A. 2012. A framework for organisational change management in lean manufacturing implementation. International Journal of Service and Operations Management, 12(1), pp. 101-117.

[16] Bhuiyan, N. and Baghel, A. 2005. An overview of continuous improvement: From the past to the present. Management Decision, 43(5), pp. 761-771.

[17] Bessant, J., Caffyn, S. and Gallagher, M. 2001. An evolutionary model of continuous improvement behaviour. Technovation, 21(2), pp. 67-77.

[18] Ras, E. and Visser, J.K. 2015. A model for continuous improvement at a South African minerals beneficiation plant. South African Journal of Industrial Engineering, 26(1), pp. 191-206.

[19] Womack, J., Jones, D.T. and Roos, D. 1990. The machine that changed the world. Rawson Associates.

[20] Liker, J.K. and Hoseus, M. 2008. Toyota culture. McGraw Hill.

[21] Saruta, M. 2006. Toyota production systems: The 'Toyota Way' and labour-management relations. Asian Business \& Management, 5(4), pp. 487-506.

[22] Womack, J. 2007 Respect for people. Lean Enterprise Institute. Retrieved from http://www.lean.org/womack/DisplayObject.cfm?o=755. [Accessed on 3 February 2016]

[23] Emiliani, B. 2008. Real lean: The key to sustaining lean management. The centre for lean business management, LLC, Wethersfield, CT

[24] Rother, M. Respect for people. The Lean Edge. Retrieved from http://theleanedge.org/?p=1849. [Accessed on 3 February 2016]

[25] Crabill, J., Harmon, E., Meadows, D., Milauskas, R., Miller, C., Nightingale, D. and Schwartz, B. 2000. Production operations level transition to lean roadmap: Production operations transition to lean team. Cambridge: MIT.

[26] Nightingale, D.J. and Mize, J.H. 2002. Development of a lean enterprise transformation maturity model. Information Knowledge Systems Management, 3(1), pp. 15-30.

[27] Liker, J.K. and Meier, D. 2006. The Toyota Way fieldbook - A practical guide for implementing Toyota's 4 Ps. Mc.

[28] Marodin, G.A. and Saurin, T.A. 2013. Implementing lean production systems: Research areas and opportunities for future studies. International Journal of Production Research, 51(22), pp. 6663-6680.

[29] Pollitt, D. 2006. Cultural change makes crusader fit for the future: Training in lean manufacturing helps to transform company. Human Resource Management International Digest, 14(2), pp. 11-14.

[30] Tsutsui, W.M. 1998. Manufacturing ideology: Scientific management in twentieth-century Japan. Princeton University Press. 